\title{
Construction of Consumer-brand Relationship Based on Information Network Era
}

\author{
Jicheng Li, Lizhu Lin \\ Harbin University of Science and Technology, Harbin, 150040, China
}

\begin{abstract}
Keywords: Consumer, Brand, Enterprise microblog, Brand trust, Brand loyalty, Variable,
\end{abstract} Regression analysis

\begin{abstract}
Construction of consumer-brand relationship by information network technology is an inevitable development tendency of enterprises in the era of new market economy. Since microblog was issued in 2009, Chinese microblog users sharply increased to 200 million within only 2 years. This also offers new marketing strategy and consumer-brand relationship construction thought for enterprises. This paper analyzes loyalty index and credibility between consumers and brand through conceptual model based on microblog interactive strategy, brand trust theory and regression theory.
\end{abstract}

\section{Introduction}

Application of microblog interactive strategy can influence product credibility and loyalty index. Thus, many enterprises will adopt such marketing strategy, take brand trust as an intermediate variable and regard internet microblog strategy as guidance to construct stable relationship between consumers and brand.

\section{Consumer-brand relationship theory based on corporate microblog strategy}

Enterprises based on information network era focus on making product brand close to consumers through internet information technology. Various marketing strategies are used to establish credibility and loyalty index about product brand. Hence, this paper mainly proposes the following theories.

\section{(I) Consumer brand interactive strategy theory based on corporate microblog}

Corporate microblog is an important approach for enterprises to advertise product brand. It drives interactions between brand and consumers. Interactive strategies based on enterprise-consumer-strategy include two types: social interactive theory and task-oriented interactive theory. Social interactive theory covers information about emotion communication among professional knowledge, brand and consumers. Besides, it alas contains general knowledge. General knowledge includes network consumer, current affairs, industrial trend and even product research report that network consumers are interested in. Task-oriented interactive theory includes product interaction, corporate image interaction and joint creation activity etc. In enterprise microblog, product interaction is mainly responsible for publishing and recommending new products and other promotion activities. Enterprise microblog will stimulate consumers' purchasing will through pictures, videos and emotional expansive language. Common creation ability is that enterprises set relevant themes through microblog, interact and comment with consumers, and hope consumers to transmit information so as to expand product brand publicity influence. Usually, interactive strategy of enterprise microblog will influence consumers' brand awareness and emotion. These are good foundation for consumers to establish consumers’ brand loyalty index.

\section{Brand trust theory}

Brand trust is an important bridge between consumers and enterprise product brand. In sociology and enterprise management fields, brand trust is a key intermediate variable. When enterprises define marketing objective as the rise in market share, they will establish close and favorable relationship 
between consumers and product brands. Trust cannot be lacked in this relation. Chinese economist Chai Junwu also considers, "brand trust should be an important bond for enterprises, enterprise products and consumers to establish long-term relationship, while trust is the most important constituent part of brand attribute”. When consumers and brand attribute generate mutual relations and establish trust, consumers will generate sense of security for the brand and gain satisfaction through benefit and welfare provided by enterprises. Hence, brand reliability is brought for consumers, i.e. brand trust. Such trust indicates once consumer groups establish trust with the product brand, even if they face the possible risks, they are willing to depend on and trust this brand.

\section{Brand loyalty theory}

Brand loyalty theory was proposed early overseas (1923). In the development for nearly 100 years, the definitions of brand loyalty exceed 200 types. Thus, there is no a uniform agreement on brand loyalty. However, it is found in theoretical researches for many years that, brand loyalty has two kinds of dimensions and they are based on attitude and behavior.

Behavioral loyalty

Behavioral loyalty is a visual manifestation of consumers on brand loyalty. It can accurately define and measure consumers' consuming behavior. When consumers continuously purchase products of a brand, this indicates consumers generate favorable impression on this brand. However, this may be because merchants carry out some commercial promotion activities or market coverage of this brand exceeds other competition brands, all these can guide consumers' consuming behavior. Some scholars believe, "brand loyalty reflects the total proportion of times of buying products of a brand in all products; higher proportion indicates consumers' higher loyalty index."

From the perspective of behavior, behavioral loyalty reflects the largest feature of brand consumers, i.e. repeated purchase. Consumers' times of repeated purchase, purchase proportion, order, possibility and duration of loyal consuming behaviors are specific expressions of loyalty.

Attitude loyalty

Consumers' brand loyalty can be regarded as an attitude, because it reflects consumers' preference to a specific brand and psychological commitment. Some experts indicate behavioral loyalty cannot completely reflect consumers' brand loyalty. When consumers admire a brand, they are really loyal to the brand. American marketing society once defined brand attitude loyalty as follows, "consumers' brand attitude loyalty reflects consumers' perception of a brand and preference degree in a long time." If enterprises hope their brand products can grasp consumers; heart, they must "make a psychological attack" and position the relationship attribute between consumers and brand as long-term and stable attitude loyalty ${ }^{[1]}$.

\section{Conceptual model hypothesis of consumer-brand loyalty and brand trust}

\section{Proposal of conceptual model}

Interactive strategy of enterprise microblog for brand products is mainly based on two core ideas: consumers' brand trust and brand loyalty. Enterprises can divide trust dimension of product brand, including brand loyalty, to construct enterprise microblog interactive strategy for their products. This strategy must contain social interaction and task-oriented interaction link. Secondly, brand integrity degree, reliability and benefaction should be combined to create brand trust structure. Consumers' behavior and attitude loyalty to a brand may be used to establish brand loyalty framework. In this way, conceptual model may form. Its composition is shown in Fig.1. 


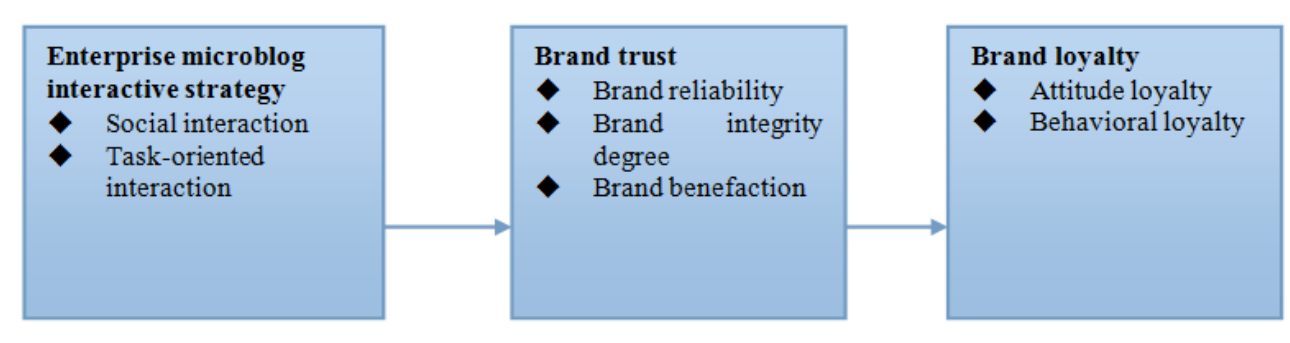

Fig. 1. Flow diagram of consumer-brand loyalty and brand trust

\section{Relevant research hypotheses}

After conceptual model is established, trust dimension hypothesis between enterprise microblog interactive strategy and product brand and relationship hypothesis between brand trust and brand loyalty should be analyzed.

Relationship hypothesis between enterprise microblog interactive strategy and brand trust

Nowadays, the main purpose of social enterprise marketing is to develop the relationship between consumes and brand, and seek the supporting point between brand trust and loyalty index. In information network era, relationship platform constructed by enterprises for consumers and product brand is microblog. Information contents published by enterprise microblog will influence consumers' emotion on the brand. It expands consumers' perception channel for commodity brand and also helps consumers to correctly judge brand product reliability and merchants' integrity. Hence, the setup of enterprise microblog should start from consumers' standpoint and consider for consumers anytime. Only in this way, interactive service and brand products promoted by enterprise microblog can present positive correlation with relevant customers, because it motivates consumers' cognitive affective response, final consumption selection and social tide pursuit awareness and influences consumers' brand trust. On the other hand, microblog is the most convenient communication tool which is used by most people in current information era. If enterprises can master various functions of microblog to promote emotion communication among consumers and fuse some humanized services in enterprise microblog to enhance microblog users' satisfaction for brand and directly influence consumers' brand trust.

Relationship hypothesis between brand trust and brand loyalty

Brand loyalty is supported by brand trust. For consumers, their attitude and behavior to brand trust may not calculate cost and benefit. It thus can be seen that consumers' brand loyalty and brand trust supplement each other. They are the "upper structure" of consumers' thought. For enterprises, trust is a key concept in enterprise microblog awareness. It represents the commitment of enterprise microblog activity to customer relations. Thus, in long-term microblog marketing interactive strategy, consumers will generate brand emotion and brand awareness. Brand emotion reflects consumers' two emotional dimensions: pleasant emotion and arousing emotion. It exactly corresponds to three dimensions of brand awareness: brand perceived quality, brand resonance and brand relevance perception. The relations among the above dimensions indicate the influence of enterprise microblog interactive strategy on consumers' emotions, and the close relationship between consumers and product brand is consolidated from diversified perspective. The intermediary force for these is brand trust. It also proves positive influence of interactivity brought by enterprise microblog on construction of consumer-product brand relationship ${ }^{[2]}$. 


\section{Empirical analysis of enterprise microblog interactive strategy in construction of consumer-product brand relationship}

\section{Statistic analysis of survey of consumers who use enterprise microblog}

To prove effectiveness of enterprise microblog interactive strategy on construction of consumer-product brand relationship and show its relevance between consumers' brand trust and brand loyalty theory, this paper conducts actual survey of enterprise microblog use. The survey contents include consumers' gender, age, education background and microblog use. The sample size is 1000 , as shown in Table 1.

Table 1. Descriptive statistical analysis of consumers who use enterprise microblog

\begin{tabular}{|c|c|c|c|}
\hline Respondent variable & Classification & Sample size (1000) & Percentage \\
\hline \multirow{2}{*}{ Gender } & Male & 500 & $50 \%$ \\
\hline & Female & 500 & $50 \%$ \\
\hline \multirow{4}{*}{ Age } & $15 \sim 22$ & 250 & $25 \%$ \\
\hline & $23 \sim 27$ & 250 & $25 \%$ \\
\hline & $28 \sim 35$ & 250 & $25 \%$ \\
\hline & Above 36 & 250 & $25 \%$ \\
\hline \multirow[t]{4}{*}{ Education background } & $\begin{array}{c}\text { Senior high } \\
\text { school/junior high } \\
\text { school, technical } \\
\text { secondary school and } \\
\text { below } \\
\end{array}$ & 300 & $30 \%$ \\
\hline & Junior college & 200 & $20 \%$ \\
\hline & University & 400 & $40 \%$ \\
\hline & Master and above & 100 & $10 \%$ \\
\hline \multirow{4}{*}{ Microblog use } & Within a half year & 150 & $15 \%$ \\
\hline & $1 \sim 2$ years & 300 & $30 \%$ \\
\hline & 2 3 years & 450 & $45 \%$ \\
\hline & Above 3 years & 100 & $10 \%$ \\
\hline \multirow{5}{*}{$\begin{array}{c}\text { Mean daily microblog } \\
\text { use times (subject to } \\
\text { login times) }\end{array}$} & 1 & 130 & $13 \%$ \\
\hline & $1 \sim 2$ & 220 & $22 \%$ \\
\hline & 3 次 & 300 & $30 \%$ \\
\hline & $5 \sim 6$ & 240 & $24 \%$ \\
\hline & Above 6 & 110 & $11 \%$ \\
\hline
\end{tabular}

According to investigation and statistics of enterprise microblog use of 1000 consumers, the quality of survey sample is high and can basically meet research needs. Besides, the samples have reference for proving the relationship among enterprise microblog interactive strategy, brand trust and brand loyalty.

\section{Regression analysis of brand loyalty and brand trust}

To further explain causal relationship among enterprise microblog interactive strategy, brand loyalty and brand trust, this paper adopts brand loyalty and brand trust which can describe the relevance between explanatory variable and explained variable and overcome some defects of causal relationship which cannot be explained. So, it has certain hypothesis significance.

Multivariate regression analysis between enterprise microblog interactive strategy and brand trust

This paper takes brand integrity for example, regards it as dependent variable of regression analysis and deems brand trust and loyalty in enterprise microblog interactive strategy as independent variables. Stepwise regression analysis is conducted by regression analysis method, as shown in Table 2. 
Table 2. Multivariate regression analysis of enterprise microblog interactive strategy on brand integrity

\begin{tabular}{|c|c|c|c|c|c|}
\hline \multicolumn{6}{|c|}{ Model } \\
\hline Model & $\mathrm{R}$ & R square & $\begin{array}{c}\text { Adjusted R } \\
\text { square }\end{array}$ & $\begin{array}{c}\text { Standard error } \\
\text { of estimate }\end{array}$ & $\begin{array}{c}\text { Durbin-Wasto } \\
\mathrm{n}\end{array}$ \\
\hline 1 & $.599 \mathrm{a}$ & .375 & .343 & .54282 & 1.788 \\
\hline \multicolumn{6}{|c|}{ a. Prediction constant, task-oriented interaction } \\
\hline
\end{tabular}

According to the data in Table 2, regression effect of social interaction and brand integrity shown by enterprise microblog interactive strategy is not obvious, while task-oriented interaction has obvious effect on brand integrity regression. The finally adjusted $\mathrm{R}$ square reaches 0.343 . This indicates variations which can be explained by multivariate regression analysis should account for $34.3 \%$ of total variations. In other words, enterprise microblog interactive strategy can positively influence consumers' brand trust.

Multivariate regression analysis between enterprise microblog interactive strategy and brand loyalty

If dimensions in brand trust serve as independent variables in multivariate regression analysis and behavior loyalty of brand loyalty serves as dependent variable, regression analysis results are shown in Table 3.

Table 3. Multivariate regression analysis of enterprise microblog interactive strategy on brand loyalty

\begin{tabular}{|c|c|c|c|c|c|c|c|}
\hline \multicolumn{8}{|c|}{ Coefficient a } \\
\hline \multirow{2}{*}{ Model } & \multicolumn{2}{|c|}{$\begin{array}{l}\text { Non-standardized } \\
\text { coefficient }\end{array}$} & \multirow{2}{*}{$\begin{array}{c}\begin{array}{c}\text { Standard } \\
\text { coefficien } \\
\mathrm{t}\end{array} \\
\text { Trial }\end{array}$} & \multirow{2}{*}{$\mathrm{t}$} & \multirow{2}{*}{ Sig. } & \multicolumn{2}{|c|}{ Colinearity statistics } \\
\hline & B & $\begin{array}{l}\text { Standard } \\
\text { error }\end{array}$ & & & & Tolerance & VIF \\
\hline (Constant) & .676 & .207 & & 9.433 & .000 & & \\
\hline $\begin{array}{l}\text { Brand } \\
\text { reliability }\end{array}$ & .538 & .064 & .518 & 8.587 & .000 & .495 & 2.024 \\
\hline $\begin{array}{c}\text { Brand } \\
\text { integrity }\end{array}$ & .319 & .078 & .276 & 4.150 & .000 & .429 & 2.349 \\
\hline
\end{tabular}

It is seen in Table 3 that, reliability of the final standard regression coefficient reaches 0.518 , and brand integrity reaches 0.276 . This shows regression effect of brand loyalty is good and obvious. We can say that two dimensions in brand trust have positive influence on regression analysis of behavioral loyalty ${ }^{[3]}$.

\section{Conclusion}

Enterprise microblog has become the most competitive enterprise marketing tool which the largest social communication ability in market economy in information network era. It not just alters people's consumption habits, but also establishes and enhances consumers' brand trust and loyalty. This paper constructs the relationship between enterprise consumers and brands based on multiple-aspect theory and hopes to shape corporate image, cultivate potential consumption force, activate market by enterprise microblog and create more product brands. This is very beneficial to development of China's market economy.

\section{References}

[1] Yan Yuxing, empirical study on influence of brand community relationship on consumer's purchase intentions based on network environment. Jilin University, 2015,6-19.

[2] Huang Jing, Xiong Wei, fracture and renewal of consumer-brand relation: theoretical review and prospect. Foreign Economics \& Management, 2007,29(7):50-55. 
[3] Zeng Yao, Influence of enterprise microblog interactive strategy on consumers' brand loyalty. Southwestern University of Finance and Economics, 2014,49-56. 